\title{
A ciência da mente: a psicologia à procura do objeto
}

\author{
Claudio Afonso Soares ${ }^{1}$ - Universidade São Francisco, Itatiba, Brasil
}

Pasquali, L. (2008). A ciência da mente: a psicologia à procura do objeto. Brasília: Editor, 406 p.

Luis Pasquali é gaúcho, formado em pedagogia, filosofia, teologia e psicologia. É doutor em psicologie pela Universidade Catolica de Louvain, Bélgica. Lecionou nos EUA e é professor emérito da Universidade de Brasília. Nesta obra o autor procura abrir caminho de uma psicologia para além da biologia, e das neurociências, enfatizando distinções fundamentais entre processos biológicos e processos mentais, a partir de uma visão evolucionista da ciência. A estrutura da obra é constituída de uma introdução, sete capítulos, referências e índices remissivos e onomásticos que facilitam a consulta de conceitos específicos, assim como sua releitura.

$\mathrm{Na}$ introdução, o autor faz um breve comentário a respeito da diversidade do objeto de estudo da psicologia de forma generalizada e explicita a razão para elaborar sua obra. Apresenta o formato de cada um dos capítulos. Comenta a respeito de suas angústias ao escrever o livro e finaliza com agradecimentos a algumas pessoas que o ajudaram com dicas a escrevê-lo.

No primeiro capítulo, intitulado $A$ psicologia como ciência: filosofia e estratégia, o autor apresenta de forma detalha a idéia da evolução natural de Charles Darwin enfocando sua influência na comunidade científica, na evolução das sociedades e outras áreas do conhecimento. Este capítulo pode ser considerado introdutório as demais, uma vez que expõe de forma clara e muito bem elaborada conceitos como singularidade, evolução, complexificação, organização, mutação e seleção natural como pilares para a exposição de fatos e teorias, sobretudo com respeito à vida e à mente, que são aprofundados nos capítulos subsequentes.

O universo: da singularidade à mátria é o titulo do segundo capítulo, cujo objetivo é descrever o surgimento do universo à luz da Astronomia, Física, Química e da Biologia. Nesse caso, os objetivos são: ter uma visão do universo da origem até hoje; detalhamento do universo primordial; eventos marcantes da história do universo; separação das forças cósmicas e o surgimento da matéria. As discussões fomentadas nesses capítulo são fundamentais para explicar o surgimento da matéria a partir do modelo padrão da física.

No terceiro capítulo, intitulado $D a$ matéria à vida, o autor discute a importância do surgimento da vida a partir de duas teorias: a teoria primitiva e teorias sobre a natureza da vida. Estuda, ainda, a história evolutiva do sistema nervoso tecendo comentários a respeito da anatomia do cérebro humano, a função do cérebro, transmissão de mensagens nervosas e funções dos neurônios espelhos. Esse capítulo expõe de forma didática e ilustrativa o desenvolvimento do sistema nervoso, analisando de forma minuciosa sua organização, estrutura, função, processos químicos, produção de energia relacionados com processos de consciência e autoconsciência no ser humano.

Da vida à autoconsciência: a mente é o título do quarto capitulo. Nele Luis Pasquali investiga o surgimento da consciência e da autoconsciência como características marcantes da mente. Para isso, expõe de forma breve algumas teorias da mente como as Teorias da Identidade, Teorias Dualistas e Teorias Interacionistas. Em seguida discute algumas propriedades típicas e essenciais da mente: o eu e a autoconsciência; a inteligência como pensamento e abstração; a linguagem e o simbolismo; a vontade e o livre-arbítrio e a cultura. Em sua conclusão, o autor indica que não se pode considerar que haja um elemento exclusivo que distinga a mente humana, mas sim um conjunto deles que pode ser expresso a partir de um conjunto metassistêmico contido no eu superior.

Buscando a Característica da mente, o autor escreve o quinto capítulo apresentando tópicos tradicionais de capacidades: cognitivas, afetivas e conativas caracterizadas como objetos da mente que são expressos como imagens, idéias, sentimentos e decisões. Esses mecanismos ou faculdades da mente atuam como manipuladores de objetos de acordo com a natureza e a estrutura próprias de cada um. Ao final de toda a exposição são elencados os principais mecanismos da mente: percepção, imaginação, intuição, raciocinio, senso estético, senso do sublime, senso do cômico, atenção vontade e significado da vida.

\footnotetext{
${ }^{1}$ Endereço para correspondência:

Universidade São Francisco - Programa de Pós Graduação Stricto Sensu em Psicologia

Rua Alexandre Rodrigues Barbosa, 45 - 13251-900 - Itatiba-SP, Brasil.

E-mail: claudiosafonso@yahoo.com.br
} 
Falar sobre o conhecimento humano oferece os mais diversos discursos e opiniões a respeito do que seja esse ser humano. É com essa afirmação que o autor começa o sexto capítulo, intitulado: $A$ teoria em psicologia: um esquema de integração, no qual enfoca a concepção de homem sobre as bases do "Homo philosophicus" (a das ciências e da Filosofia) e a do "Homo theologicus" (da Teologia). Nesse contexto, o homem pode ser considerado como a confluência da evolução natural e da intervenção divina.

O último capítulo, da consciência ao espírito: a alma (o pneuma), apresentado em forma de parábola, trata da evolução da mente a partir da Teologia. A análise é feita tendo como parâmetro a influência do mundo espiritual na formação da essência humana. Para tanto, a atitude do homem não dependeria mais dos aspectos racionais ou cognitivos, haja vista que o alicerce estaria na fé e na hermenêutica.

A ciência da mente: a psicologia à procura do objeto é um livro que oferece aos profissionais e estudantes de psicologia um esboço ou contexto de referência, o mais evidente possível, a partir do qual pesquisadores podem se orientar e utilizá-lo como fonte de pesquisa. Trata-se de uma obra muito interessante, uma vez que aprofunda discussões acerca dos objetos de estudos das psicologias. Cabe destaque o cuidado com que trata a diversidade dos sistemas psicológicos historicamente construídos. Sua organização permite que, ao final da obra, o leitor faça interpretações que julgue pertinentes à construção de um projeto epistemológico de ser humano para além da mente humana.

Considero que o livro é excelente por seus aspectos científicos, filosóficos teológicos, por sua atualidade temática e bibliográfica. Portanto, é uma obra útil para profissionais, estudantes e pesquisadores ocupados com a psicologia enquanto ciência e profissão.

Sobre o autor

Claudio Afonso Soares é psicólogo, especialista em Educação Especial e mestrando pelo Programa de PósGraduação Stricto Sensu Psicologia da Universidade São Francisco. 